\title{
Highway Traffic Management using Smart Toll Plaza
}

\section{J. J. Nandhini, K. Premalatha}

\begin{abstract}
Nowadays for paying the tax at tollgates there is a heavy rush/traffic. In order to reduce the traffic congestion near Toll plazas and to save the time, payment can be made in advance using an android app along with RFID tag. An android app is developed based on i-Beacon Technology which will communicate to the RFID readers at the toll gates. The bank account of user is connected to the user's app installed in his/her mobile. The verification of payment at the toll gates can be done with RFID and $i$-Beacon technology. On selecting the route of travel/journey the user can pay through the android app. If the payment has been done already toll gate opens, else the customer has to pay the toll tax manually. For further toll gates, the beacons will connect to the payment app to verify the payment details.
\end{abstract}

Keywords- Toll tax, smart-RFID, i-Beacon technology, Android app

\section{INTRODUCTION}

In the present toll collection system, each vehicle needs to be wait and pay the toll tax. The approximate time required by the vehicle is 60 seconds, therefore $60 \times 7=420$ seconds for a week. For a year, it will be $1800 \times 12=2,16,200$ seconds which is equal to 6 hours. From this, a vehicle that enter the toll gate at least one time a day in a year will waste 6 hours for paying the tax alone. This six hours' wastage increases the consumption of fuel, engine system's life span.

By using the proposed methodology, we can minimize the traffic density, waiting time for toll payment and $\mathrm{CO} 2$ emission by transportation [1] means and money. Since heavy traffic density is also one of the most reasonable event which leads to accidents [2]. The manufacturer will include the RFID tag which contains the required details of the user. The payment detail verification is done by this RFID tag while the vehicle crosses the toll gate. The app is used by the user to make this process as simpler one.

In order to save the time and avoid traffic congestion at the toll gates, a smart toll system can be used. In such a system, RFID tags are attached to the vehicle. This tag is scanned by a RFID reader at toll gate [3]. The data contained is sent to the Database Management System(DBMS) using a microcontroller for the verification of payment. The RFID tag is scanned by the reader only for the first toll gate the vehicle crosses. For further toll gates, iBeacon technology is used. The beacon will be installed in all the toll gates. These beacons will communicate with the mobile phone of the user through Bluetooth signals to transfer the details of the payment.

Revised Manuscript Received on 14 August, 2019.

J.J.Nandhini, Electrical and Electronics Engineering,Kumaraguru College of Technology, Coimbatore-641049, Tamil Nadu, India.(Email: nandhini.jj.eee@kct.ac.in)

K.Premalatha, Electrical and Electronics Engineering, Kumaraguru College of Technology, Coimbatore-641049, Tamil Nadu, India.(Email: premalatha.k.eee@kct.ac.in)

\begin{tabular}{|l|l|l|l|l|}
\hline \multicolumn{1}{|c}{ Table ISmart Toll Gates In India } \\
\hline $\begin{array}{l}\text { Name of } \\
\text { roadway }\end{array}$ & $\begin{array}{l}\text { Type of } \\
\text { roadway }\end{array}$ & $\begin{array}{l}\text { Owned } \\
\text { by }\end{array}$ & Operated by & Location \\
\hline FASTag & Highway & NHAI & $\begin{array}{l}\text { Highways } \\
\text { Management } \\
\text { Company } \\
\text { Limited }\end{array}$ & Pan-India \\
\hline $\begin{array}{l}\text { NH-6 toll } \\
\text { road }\end{array}$ & Highway & NHAI & $\begin{array}{l}\text { TollTrax Toll } \\
\text { Collection } \\
\text { System }\end{array}$ & $\begin{array}{l}\text { Kharagpur, In } \\
\text { dia }\end{array}$ \\
\hline $\begin{array}{l}\text { Bandra-Worli } \\
\text { Sea Link } \\
\text { Rajiv Gandhi } \\
\text { Sea Link) }\end{array}$ & Highway & $\begin{array}{l}\text { MSRDC } \\
\text { HCC }\end{array}$ & $\begin{array}{l}\text { MEP } \\
\text { Infrastructure } \\
\text { Developers }\end{array}$ & Mumbai, India \\
\hline $\begin{array}{l}\text { Delhi } \\
\text { Gurgaon } \\
\text { Expressway }\end{array}$ & Highway & NHAI & $\begin{array}{l}\text { Electronic Toll } \\
\text { Collection } \\
\text { Systems }\end{array}$ & Delhi, India \\
\hline $\begin{array}{l}\text { Lucknow } \\
\text { Sitapur } \\
\text { Expressways } \\
\text { Ltd }\end{array}$ & Highway & NHAI & $\begin{array}{l}\text { Rajdeep - Toll } \\
\text { Management } \\
\text { System }\end{array}$ & Uttar Pradesh, \\
\hline $\begin{array}{l}\text { GMR } \\
\text { Ambala- } \\
\text { Chandigarh } \\
\text { Expressway }\end{array}$ & Highway & NHAI & $\begin{array}{l}\text { Rajdeep - Toll } \\
\text { Management } \\
\text { System }\end{array}$ & $\begin{array}{l}\text { Haryana } \\
\text { Punjab, India }\end{array}$ \\
\hline $\begin{array}{l}\text { GMR } \\
\text { Ulunderpet } \\
\text { Expressway }\end{array}$ & Highway & NHAI & $\begin{array}{l}\text { IBI Group } \\
\text { India }\end{array}$ \\
\hline $\begin{array}{l}\text { Kumarapalay } \\
\text { am toll road }\end{array}$ & Highway & NHAI & Efkon Group & $\begin{array}{l}\text { Tamilnadu, } \\
\text { India }\end{array}$ \\
\hline
\end{tabular}

In these toll gates, electronic collection involves the deduction of amount from an ICICI bank account (considered account) [3]- [7]. The user should possess enough balance in the account. If the balance is insufficient, manual payment is to be done. The user has to create an account for this purpose.

In order to avoid this separate account creation, the payment can be made in prior through an app in mobile phone. The account can be of any banks in India. Some smart toll plazas are available in India which is listed in TableI(Source:https://en.wikipedia.org/wiki/List_of_electro nic_toll_collection_systems).

\section{PROPOSED METHODOLOGY}

The block diagram description and connection diagram of the proposed system with its component is shown below Figure 1. and Figure 2.

Published By:

Blue Eyes Intelligence Engineering \& Sciences Publication 


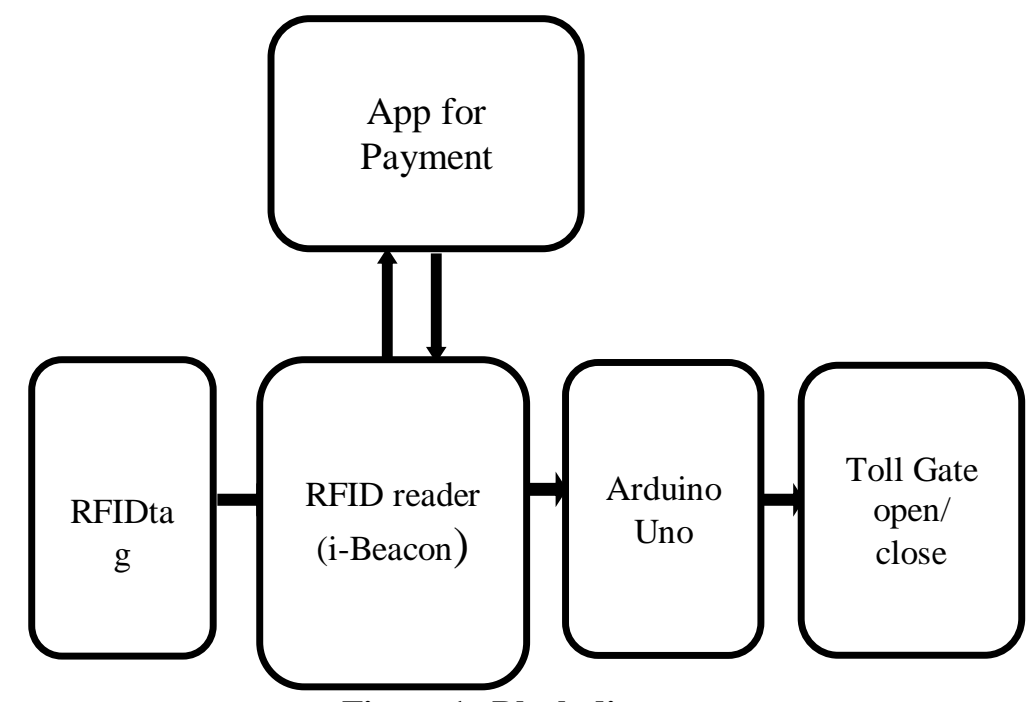

Figure 1. Block diagram

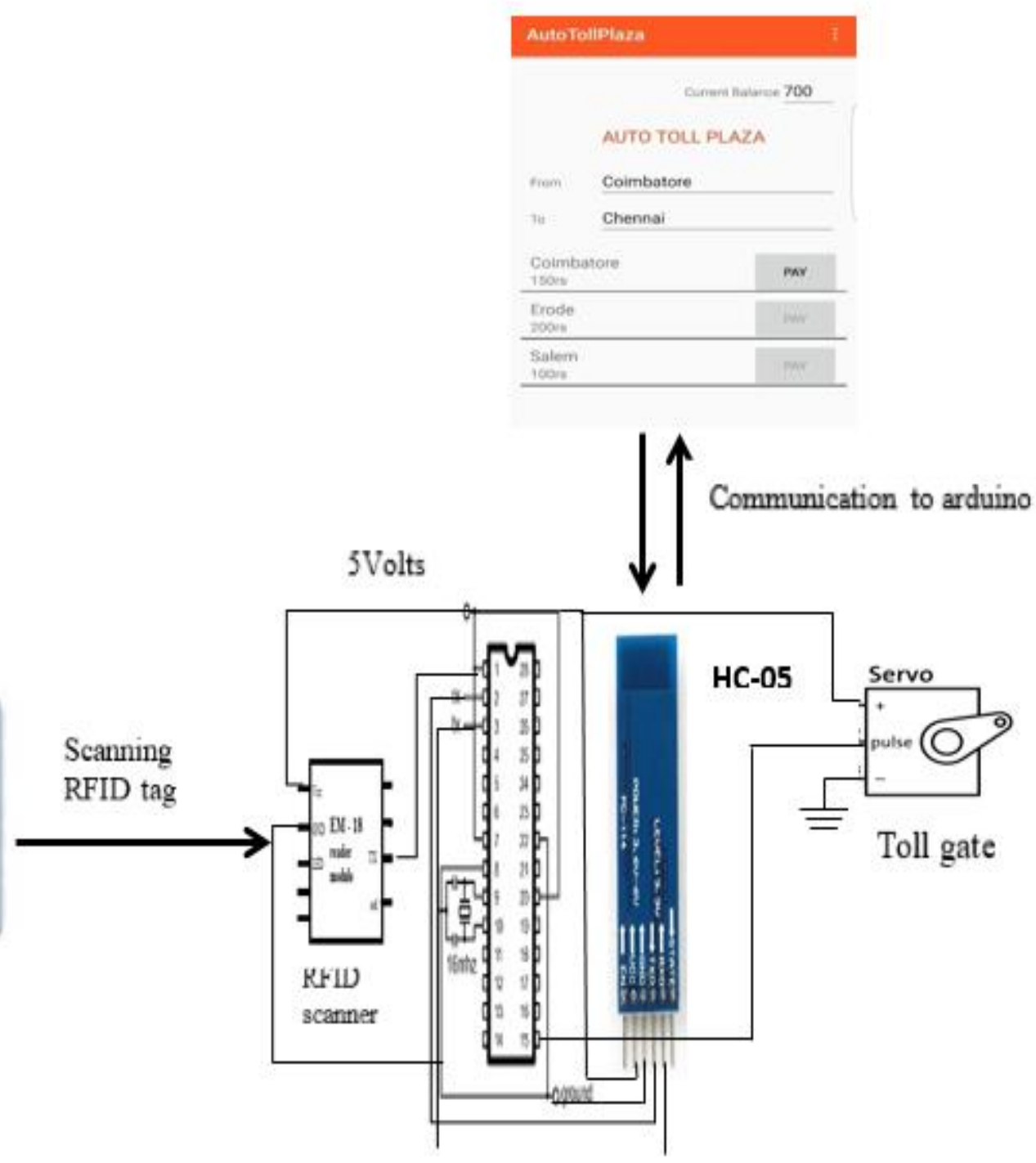

Arduino Uno

Figure 2. Connection diagram

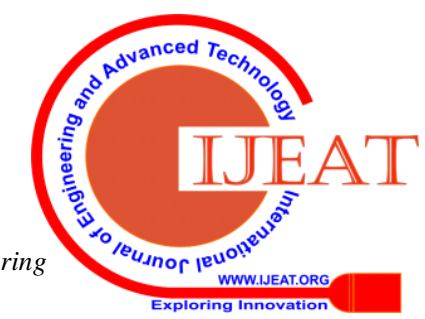


The components used are as follows:

$\begin{array}{ll}\text { - } & \text { App for payment } \\ \text { - } & \text { RFID tag } \\ \text { - } & \text { RFID reader } \\ \text { - } & \text { Arduino } \\ \text { - } & \text { Launch pad }\end{array}$

A. RFID tag reader:

Radio waves is used to capture the details in the RFID tag.

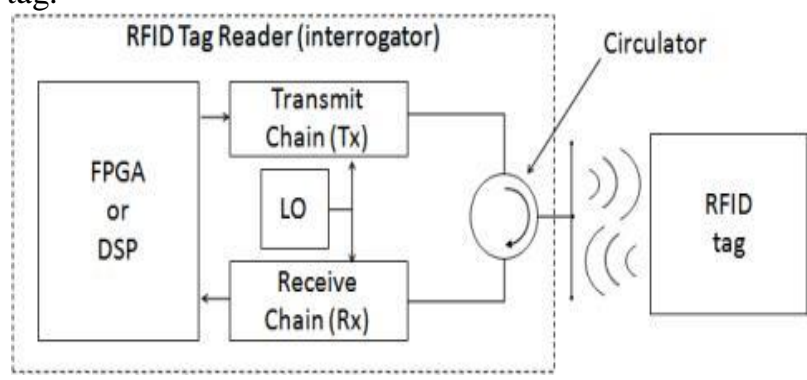

Figure 3. Components of an RFID reader

The rode data is communicated to Database management system. The reader consists of antenna to communicate with the RFID tag Figure 2. The reader has the ability to communicate to the RFID tag without a direct Line of Sight(LOS), depending on radio waves frequency and the type of the tag such as active or passive or semi passive used. Readers can process multiple tags simultaneously [4]. This increases processing items to avoid congestion. These readers can be mobile or stationary. There are two classification of RFID Tags [5], [6]

\section{B. Beacon Technology}

Beacon is a protocol which was introduced by Apple at the Apple Worldwide Developers Conference in 2013. Numerous vendors have since designed beacon compatible hardware transmitters that are called beacons. These beacons are a class of BLE devices that communicate with their nearby devices to identify them. The technology helps tablets, smartphones and other devices to perform actions when it is closer to a beacon. These beacons can also be used to track the user's location. Location based actions can be triggered by using information sharing.

The features of beacon are as follows:

- Weather proof Enclosure

- $\quad$ Range: $75 \mathrm{~m}$ to $120 \mathrm{~m}$ at max power

- $\quad$ Size: $30 \mathrm{~mm}$ x $10 \mathrm{~mm}$ disk; Weight: 7 grams

- $\quad$ Replaceable CR2032 3V Li battery

- Integrated push-button with LED indicators

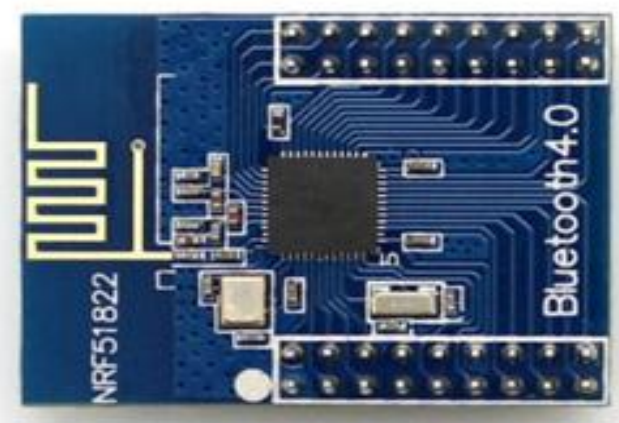

Figure 4. Beacon module (standard)
Beacon is based on BLE range in which the beacon system have one or more beacons which can transmit their own identification number to its surrounding environment as shown in Figure 3.

The beacon which receives the data will perform several operations.

The range of communication is categorized according to the distance immediate (within few centimetres), near (with a couple of meters, or greater that 10 meters away. According to customer's proximity, the beacon would perform the operation.

\section{SOFTWARE DESCRIPTION\& RESULTS}

The user has to pay via an app prior to travel. In the app, first the user has to login using his/her username \& password and select the starting and destination points. On selecting those places, the app will display how many toll gates are there in between. The user now can choose how many toll gates will be crossed so that app will display the total amount for the selected toll gates. The payment will be made once the user clicks the pay option. The account of the user is identified by the RFID number which is already linked with the user's account. The amount will automatically be deducted from account that is already linked with the RFID. Once the payment is done, the corresponding RFID is updated in the DBMS of tollgate. When the corresponding vehicle crosses the toll gate, the RFID number will be deleted from the database of that particular toll gate automatically.The application for the user's phone is developed in Android Studio as shown in Figure 4.

The system requirements to support Android Studio are

- OS versions: Windows10/8/7, Mac OS X or higher up to 10.11 .6 or 10.12.3, GNOME or KDE desktop

- $\quad$ RAM: 3GB (min), 8GB (recommended)

- Disk space: 500MB for Android Studio, at least 1.5BG for Android SDK, emulator system images and caches

- Java version: Java development kit 8

- $\quad$ Screen resolution: 1280x800 (min)

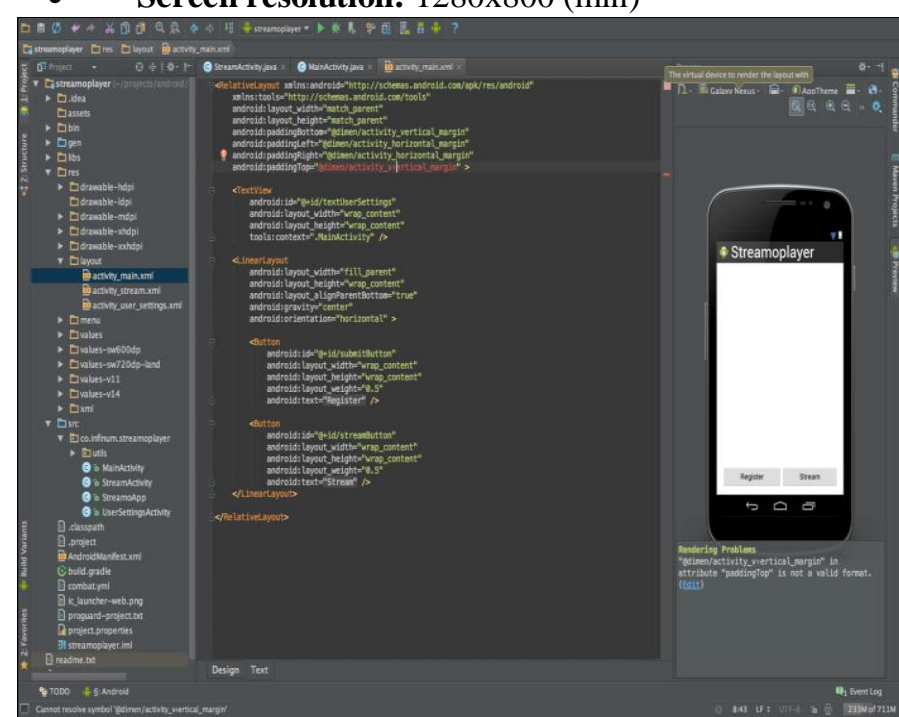

Figure 5. Android Studio- Editor

Published By: Blue Eyes Intelligence Engineering \& Sciences Publication 


\section{HARDWARE DESCRIPTION}

While travelling, the user approaches the first toll gate. Then the RFID reader will scan the RFID tag that is attached to the vehicle. The reader will scan the tag when the vehicle is a few metres away. The reader will extract the details and send it to the DBMS using a microcontroller. Now the verification of the payment is done by checking for RFID number scanned by the reader to be in the database that is already updated with the paid RFID numbers. The simple connection diagram is shown in Figure 5 [3].

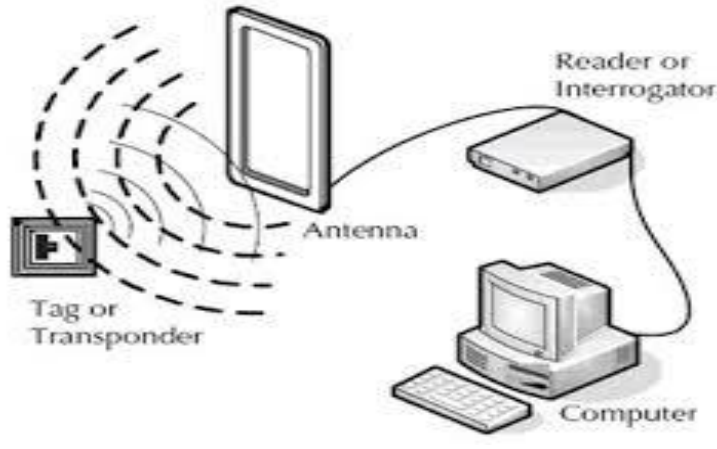

Figure 6. Smart Toll gate-DBMS

If the RFID number exists in the database, it is confirmed that payment has been done. The toll gate is opened automatically. If the RFID number does not exist in the database, the toll gate will not be opened. The user has to do the manual payment and the gate will be opened. Even though automatic toll cash collection system for road transportation exists [7], the technology usage makes the system more efficient and effective one.

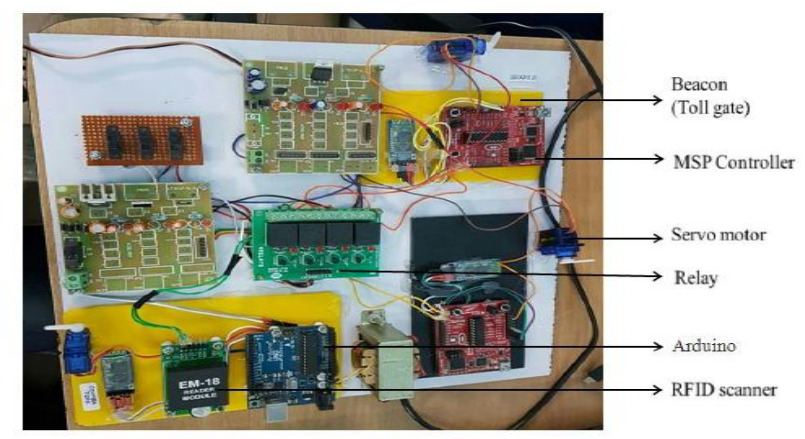

Figure 7. Prototype/Model - Hardware Connection

The above procedure is done only for the first toll gate the vehicle crosses during the travel. For further toll gates, beacon technology is used. When the vehicle approaches the toll gate, the Bluetooth of the user's mobile phone is activated by the Bluetooth signal sent by the beacons. The beacons communicate to the payment app to transfer the vehicle details to the database through microcontroller. The same verification process is followed in other toll gates as in the first toll gate. The only difference is in the details transfer to the database. The prototype/model for the one registered user is shown in Figure 6. and the output results were validated.

\section{CONCLUSION}

The RFID based smart toll system is designed to save the time and fuel wasted in waiting at the tolls to pay taxes. This system is the development of sustainable technology that reduces traffic congestion and regulates pollution. It provides a stable and reliable tracking technology. It is an efficient method of collecting, managing, disseminating, storing and analyzing the information. This system helps in reducing the delays caused while waiting in a queue and also reduces noise. It offers high security, far distance communication and low cost. It benefits both toll authority as well as the public. Hence it is the best solution over traffic jam and time consumption.

This type of smart system can be advanced by using WiFi instead of Bluetooth so that the communication distance can be increased. The access to the wireless network resources can be done from any convenient location. This reduces the cost and complexity of implementation. More number of customers can be served quickly. This gives faster response by using Data Base Management System (DBMS)

\section{REFERENCES}

1 J.J.Nandhini, D.Maria Monica,"Global Emission of Carbondioxide reduction by generation power from Carbondioxide", International Journal of Advanced Technology \& Engineering Research (IJATER), ISSN No: 2250-3536, pp. 165-171

2 Dr.K.Premalatha, Ms.J..J.Nandhini, "IoT based accident prevention and Emergency services", Research Journal of Engineering and Technology, Vol. 8, Issue: 4,2017

3 Pranoti Salunke, Poonam Malle, Kirti Datir and Jayshree Dukale, "Automated Toll Collection System Using RFID", IOSR Journal of Computer Engineering, Vol. 9, Issue 2, pp. 61-66

4 Atif Ali Khan, Adnan I. Elbejaoui Yakzan and Maaruf Ali, "Radio Frequency Identification (RFID) Based Toll Collection System", IEEE Conference on Computer Intelligence, 2015

5 Tejonidhi Aphale, Rahul Chaudhari and Jinit Bansod, " Automated Toll Plaza Using RFID and GSM", International Journal on Recent and Innovation Trends in Computing and Communication, Vol. 2, Issue 9

6 Sahil Bhosale1, Rohit Chavan2, Sunil Bhadvan, and Prajakta Mohite, "Automatic Vehicle Identification And Toll Collection Using RFID" International Research Journal of Engineering and Technology, Vol. 3 Issue 2, 2016

7 S.D.Galande, S.J.Oswal, V.A.Gidde, N.S.Ranaware and S.B.Bandgar, "Automated Toll Cash Collection System for Road Transportation", International journal of Computer Science and Mobile Computing Vol. 4, Issue 2, 2015 